\title{
Apothecary Abbreviations and weights
}

B recipe, take

3 scruple 20 grains 1.296 grams

3 drachm 60 grains 3.888 grams

$\xi$ ounce $\quad 480$ grains $\quad 31.104$ grams

ss abbreviation for the Latin semisse meaning half

§ss half an apothecary ounce 